\title{
PROBLEMS IN THE GEOLOGY OF THE HAURAKI GOLD FIELDS, NEW ZEALAND.
}

\section{A. M. Finlayson.}

The Hauraki gold fields of New Zealand, noted in former times for the remarkable bonanzas of the Thames and Coroman$\mathrm{del}$, and of late years for the progress and prosperity of the Waihi mine and its smaller neighbors, show geological features typical of the Tertiary andesitic gold fields of the Pacific and of central Europe. The district has been studied by several workers notably by F. W. Hutton, James Park, Alex McKay, S. H. Cox, J. M. Maclaren, P. G. Morgan, J. M. Bell and Colin Fraser, while visiting geologists have also written accounts of the field. The petrography has lately been investigated by Prof. W. J. Sollas in a government monograph, while the district is now being surveyed in detail by the officers of the geological survey. ${ }^{1}$

These gold-fields give exceptional opportunities for studying three closely related problems, namely, the nature of the propylitic facies of the andesites and dacites which enclose the veins, the causes of the oreshoots and ore-enrichment, and the source of the gold and silver. These three questions are discussed in the present paper, and it is convenient to begin with the alteration of the rocks, as the discussion of the other two points requires a knowledge of this.

\section{ALTERATION OF THE ENCLOSING ROCKS.}

The country-rock of the veins is a series of andesitic and dacitic lavas and tuffs, of which the dominant ferro-magnesian minerals are, in different types, hornblende, hypersthene and augite. Biotite and olivine are absent or rare. In the neighborhood of the veins the rocks are altered to a greyish-white propylitic rock, but the extent of alteration is variable, and a suite of

${ }^{1}$ For literature see bibliograhy at the end of this paper. 
specimens showing transitions from fresh andesite to completely altered rock is difficult to procure, especially in the northern districts. Thus the alteration may be pronounced on one wall of a vein and feeble on the opposite wall, it differs in different parts of the same mine as well as in different mines, and a vein generally passes through several flows of altered tuffs and lavas of different composition, and in their completely altered state such differences may not be recognizable. In order to eliminate errors arising from these causes it was necessary to collect and examine a large series of specimens from different parts.

DESCRIPTION OF THE ALTERED ROCKS.

In the progressive change from fresh to altered rock, two general types may be distinguished: (I) a chloritised or partially altered rock (grïnstein), which is widely distributed, and (2) the completely altered rock ("propylite" of New Zealand writers), which is confined to the neighborhood of the veins.

In the first type the ferro-magnesian minerals are replaced by pseudomorphs of green fibrous chlorite (generally penninite), while the plagioclase remains fresh or may be partially altered to carbonates and sericite. Hypersthene and hornblende are the first minerals to change, being altered to chlorite, with carbonates, granular quartz, or magnetite. Augite resists alteration to a greater degree, and may at times pass through an intermediate stage of uralite. This type of altered rock is almost universally distributed over these gold fields, unchloritized specimens being not readily procurable.

In the second type of alteration the rock becomes light-grey or greyish-white in color, the original felspars are represented by opaque white spots, and fine pyrite is scattered through the rock. The chlorite of the original dark silicates is destroyed and its place taken by carbonates and magnetite, the latter often fringed with leucoxene, while pyrite occurs in scattered grains and strings and as a product of replacement of magnetite. Pyrite also forms granular pseudomorphic aggregates occupying the place of original ferro-magnesian minerals. Siderite is abundantly developed from chlorite and magnetite, appearing as gray- 
ish-brown and rather opaque masses. By reflected light the mineral is dull white and often shows its cleavage-lines. This is the species which appears to have been frequently referred in these rocks to leucoxene, ${ }^{1}$ but an examination of residual magnetite in a specimen gave no trace of titanium, and the uniformity of low percentage of titanium in these rocks precludes the possibility of so much of the greyish-brown mineral being leucoxene. It is very similar to the siderite of the Tonopah altered andesite, described by J. E. Spurr. ${ }^{2}$ The felspars are completely replaced by finely divided carbonates and sericite, the aggregate generally preserving the outlines of the original crystals. Secondary quartz granules are not uncommon, and at times a mosaic of fine granular quartz may replace the felspars. Valencianite (adularia), a mineral first observed in the Waihi veins by Lind. gren, ${ }^{3}$ occurs also as a secondary product in the completely altered rocks of Waihi. It forms glassy low-polarizing pseudomorphs after the soda-lime felspars, while it also occurs filling cracks and spreading into the original crystals by gradual replacement. The Waihi valencianite carries too much soda for typical adularia, and is intermediate in composition between that species and albite both of which have of late years been frequently found in association with gold-quartz. ${ }^{4}$ The mineral was separated and analyzed by the writer, with the following result, the composition of adularia from Tonopah, and of albite (Dana) being inserted for comparison:

\begin{tabular}{|c|c|c|c|c|c|c|}
\hline & S.G. & $\mathrm{SiO}_{2}$ & $\mathrm{Al}_{2} \mathrm{O}_{3}$ & $\mathrm{~K}_{2} \mathrm{O}$ & $\mathrm{Na}_{2} \mathrm{O}$ & $\begin{array}{l}\text { Total } \\
\text { I00.00 }\end{array}$ \\
\hline I. Adularia, Tonopah ${ }^{5} .$. & 2.57 & $65.5^{2}$ & I8.59 & I 5.44 & 0.45 & 100.00 \\
\hline 2. Valencianite, Waihi & $2.6 \mathrm{I}$ & 65.85 & I 8.48 & II .25 & 4. I I & 99.69 \\
\hline 3. Albite $\ldots \ldots \ldots \ldots \ldots$ & 2.624 & 68.70 & 19.50 & & II 80 & 100.00 \\
\hline
\end{tabular}

In view of the fact that this orthoclase is, in the specimens examined, of secondary origin, while the primary felspars are soda-

${ }^{1}$ Hutton, Rep. Austr. Ass. Adv. Sci., I., I887, p. 258.

2 "Geology of Tonopah," Professional Paper No. 42, U. S. Geol. Survey, I905, p. 248.

${ }^{8}$ Eng. and Min. Journal, 79, 1905, p. 220.

"W. Lindgren, "Orthoclase as a Gangue Mineral in Fissure-veins," Am. Journ. Sci., 4th ser., Vol. 5, I898, p. $4 \mathrm{I} 8$.

${ }^{5}$ J. E. Spurr, loc. cit., sup., p. 87 . 
line varieties, the original rocks appear to have been in the main dacites and andesites. Prof. Sollas, however, has classed some specimens as altered pyroxene rhyolites and trachytes, ${ }^{1}$ and it should be noted that fresh rhyolites do occur in some parts of the southern district, with the more basic rocks. The presence of soda in the Waihi valencianite is doubtless due to its derivation from soda-felspars by the action of the potash-bearing vein-solutions. $^{2}$ Mr. P. G. Morgan has identified two lime-bearing zeolites, stilbite and laumontite, in the altered rocks of Waihi where they occurred in cavities and as small veinlets. ${ }^{3}$ They have doubtless been formed at shallow depths during the destruction of the soda-lime felspars.

The groundmass of the completely altered rocks is composed of finely divided carbonates, sericite, pyrite, and more or less secondary quartz. Progressive silicification is very marked at Waihi. Epidote is not very characteristic of these rocks, which differ in this respect from Rosenbusch's type-rock. The mean specific gravity of fresh hornblende-andesite from the Thames is 2.688 , that of the completely altered rock is $2.3 \mathrm{I} 2$.

\section{NOMENCLATURE.}

The history of the term propylite in petrographic nomenclature is now familiar and need be recounted. Its use as a term descriptive of the thermally altered phases of andesitic rocks on Tertiary gold fields has been abandoned, notably by Lindgren, ${ }^{4}$ Spurr, ${ }^{5}$ and Von Inkey, ${ }^{6}$ on account of the varying nature of the altered rock in different districts, while its etymology, dating from a time when age-difference became a basis of rock-classification, is equally open to objection. The term propylitic facies,

1 "Rocks of Cape Colville Peninsula," Wellington, I906, II., pp: I7-19, and 67.

${ }^{2}$ The possibility of secondary orthoclase was suggested for these rocks by Dr. Malcolm Maclaren (Gold, London, 1908, p. 315).

${ }^{3}$ Trans. Austr. Inst. Min. Eng., 8, 1902, p. 186.

'Trans. Amer. Inst. Min. Eng., 33, 1903, p. 798.

${ }^{5}$ Professional Paper No. 42 (Tonopah), U. S. Geol. Survey, I905, p. 236.

- Internat. Geol. Congress, sess. Io, Mexico, I906, Vol. I., p. 508. 
however, retains its significance as applied to the general type of altered rock. Zirkel's use of the term propylite as a primary rock type-a deep-seated representative of dacite-porphyrite and diorite-porphyrite, has not met with general acceptance.

In New Zealand, the use of the term propylite on the Hauraki gold fields was advocated by Prof. J. Park, ${ }^{1}$ and the word was commonly used in the former reports of the New Zealand Geological Survey. Prof. Sollas, however, in his monograph on these rocks, accepts Zirkel's definition of propylite, so that an unfortunate confusion of terms has arisen. Again, New Zealand writers applied the term to the completely altered rock (sericite-pyritecarbonate rock), whereas Bela von Inkey defines the propylitic facies as chloritized andesite (grünstein). In the face of these and other confusions arising from the varying use of the term, and the varying nature of the altered rocks to which it has been applied, it is obviously advisable to abandon the term.

PRODUCTS OF WEATHERING.

The altered rocks in general are very susceptible to the action of surface-waters in the neighborhood of the vein-fissures. Under these conditions the rocks become soft, earthy, and ironstained, with destruction of pyrite. The two chief products resulting are abundant kaolin and iron oxides. The unweathered rocks are free from these products, kaolin being not a product of alteration by the vein solutions on these goldfields. This bears out the statement of Lindgren that kaolin does not generally occur with carbonates and sericite formed by metasomatic processes. $^{2}$

Chemical changes.

I. Thames.-The following analysis of a series of specimens from the Halcyon mine, illustrate the changes in the various constituents.

1 "Geology of Hauraki Goldfields," Trans. N. Z. Inst. Min. Eng., I., I897, p. 25 .

2 "Metasomatic Processes in Fissure-veins," Trans. Amer. Inst. Min. Eng., 30, 1900, p. 614. 


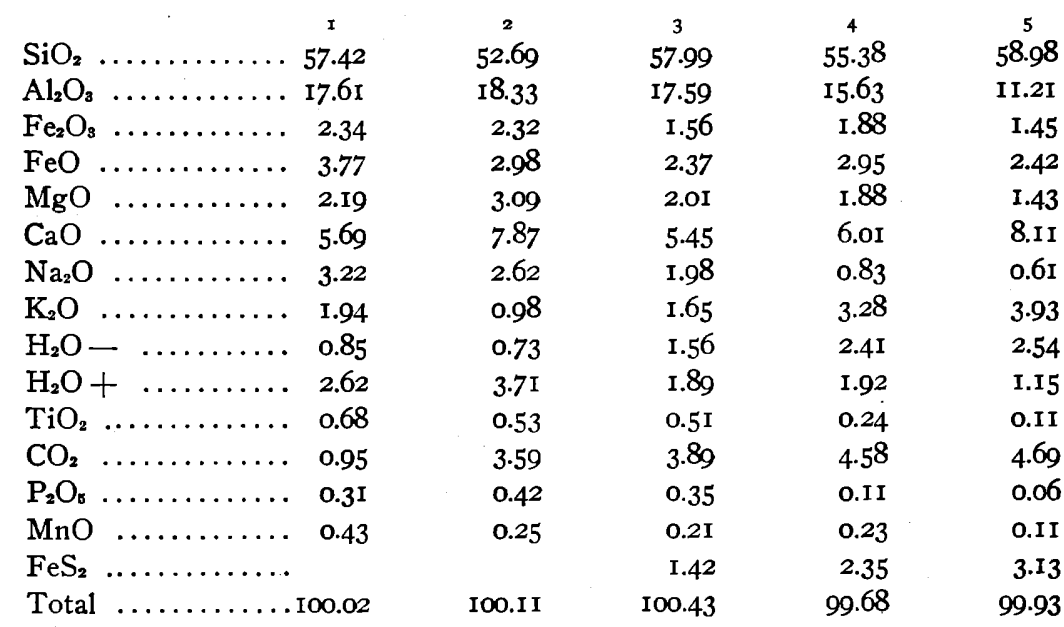

I. Fresh hornblende andesite, Thames.

2. Chloritized hornblende andesite, Halcyon mine.

$\begin{aligned} & \text { Sericite- } \\ & \text { pyrite- } \\ & \text { carbonate } \\ & \text { rock. }\end{aligned}$$\left\{\begin{array}{c}\text { 3. Altered andesite, I4 feet from Ophir vein, Hal- } \\ \text { cyon mine. } \\ 4 \text { Altered andesite, } 5 \text { feet from Ophir vein, Hal- } \\ \text { cyon mine. } \\ \text { 5. Altered andesite, adjoining Ophir vein, Halcyon } \\ \text { mine. }\end{array}\right\} \begin{aligned} & 386 \text { feet } \\ & \text { level. }\end{aligned}$

The progressive changes in the constituents may be summed up as follows: With chloritization of the hornblende there is a preliminary loss of silica. which is afterwards restored, but there is no marked net change in this constituent. Alumina, along with titanium and phosphoric oxides, is reduced in the rock close to the vein. The loss of iron oxides is more than balanced by the formation of pyrite. There is a loss of soda and gain of potash, characteristic of the propylitic type of alteration. Magnesia is also reduced, with a corresponding increase of lime, and the rock has gained much carbon dioxide, chiefly in the chloritic phase of alteration.

In the vein-zone the waters were evidently rich in potash and poor in soda, and suffered a depletion of the former and addition of the latter by their interaction with the feldspars and the formation of sericite and adularia. The solutions must have been highly siliceous, but the bulk of their silica was deposited in the 
fissures, there being no marked silicification of the adjoining rocks.

2. Waihi.-The next series of analyses, of specimens from a cross-cut to the Empire vein, Waihi Mine, shows the extensive replacement and silicification of the rocks, which has been very marked during vein-formation at Waihi, and which is similar in this respect to the processes of vein-formation at Tonopah. ${ }^{1}$

\begin{tabular}{|c|c|c|c|c|c|c|}
\hline $\mathrm{SiO}_{2} \quad \ldots \ldots \ldots \ldots$ & $\begin{array}{c}\mathbf{I} \\
63.45\end{array}$ & $5^{2} 8.39$ & $\begin{array}{l}3 \\
6 \mathrm{I} .78\end{array}$ & $\begin{array}{c}4 \\
69.35\end{array}$ & $\stackrel{5}{76.6 I}$ & $\begin{array}{c}6 \\
85.65\end{array}$ \\
\hline $\mathrm{Al}_{2} \mathrm{O}_{3} \quad \ldots \ldots \ldots \ldots$ & $\mathrm{I} 5.26$ & 16.51 & $\mathrm{I} 4.89$ & II. 66 & $8.3 \mathrm{I}$ & I.35 \\
\hline $\mathrm{Fe}_{2} \mathrm{O}_{3} \ldots \ldots \ldots \ldots$ & 2.28 & 2.46 & 2.08 & I.53 & I. 08 & 0.43 \\
\hline $\mathrm{FeO} \ldots \ldots \ldots \ldots$ & 3.01 & 2.98 & $2.5 \mathrm{I}$ & 1.66 & 0.59 & $0.2 \mathrm{I}$ \\
\hline $\mathrm{MgO} \ldots \ldots \ldots$ & 1.29 & I.66 & 1.08 & 0.46 & $0.5 \mathrm{I}$ & $0.3 I$ \\
\hline $\mathrm{CaO} \ldots \ldots \ldots \ldots$ & 3.44 & 4.08 & 3.16 & 2.09 & $3.6 \mathrm{I}$ & 2.56 \\
\hline $\mathrm{Na}_{2} \mathrm{O} \quad \ldots \ldots \ldots$ & $2.2 \mathrm{I}$ & 2.08 & 2.18 & 1.06 & 0.29 & 0.28 \\
\hline $\mathrm{K}_{2} \mathrm{O} \ldots \ldots \ldots \ldots$ & I. 78 & 2.89 & 3.68 & 3.31 & I.98 & I.4I \\
\hline $\mathrm{H}_{2} \mathrm{O}-\ldots \ldots \ldots$ & I.IO & $2.4 \mathrm{I}$ & 1.89 & I.6I & 0.43 & 0.24 \\
\hline $\mathrm{H}_{2} \mathrm{O}+\ldots \ldots \ldots$ & 2.90 & 2.87 & 3.05 & 2.12 & 1.08 & I.33 \\
\hline $\mathrm{TiO}_{2} \ldots \ldots \ldots$ & 0.75 & 0.68 & 0.69 & 0.43 & 0.28 & tr. \\
\hline $\mathrm{CO}_{2} \ldots \ldots \ldots \ldots$ & I.08 & I. 56 & 2.01 & 2.24 & I. 87 & 2.04 \\
\hline $\mathrm{P}_{2} \mathrm{O}_{5} \ldots \ldots \ldots \ldots$ & 0.29 & $0.3 \mathrm{I}$ & 0.30 & 0.26 & O.I I & tr. \\
\hline $\mathrm{MnO} \ldots \ldots \ldots$ & 0.36 & 0.32 & 0.28 & o.I I & o.I I & 0.12 \\
\hline $\mathrm{FeS}_{2} \ldots \ldots \ldots \ldots$ & & & 0.65 & 1.88 & 3.59 & 4.69 \\
\hline Total ........... & 99.20 & 99.20 & I00.23 & 99.77 & 100.45 & 100.62 \\
\hline
\end{tabular}

I. Fresh hornblende dacite, Waihi.

2. Chloritized hornblende dacite, 45 feet from Empire vein.

3. Altered dacite, 30 feet from Empire vein.

4. Altered dacite, I5 feet from Empire vein.

5. Altered dacite, adjoining Empire vein.

6. Replacement-ore, Empire vein.

850 feet level.

Taking the series from No. I (fresh dacite) to No. 6 (replacement-ore), it will be noticed that silica is reduced and carbondioxide increased in the chloritized type (No. 2), exactly as at the Thames. Subsequently, silica shows a steady increase, culminating in the highly silicified rock which composes much of the vein-material (No. 6). Alumina, together with titanium and phosphoric acids, has been reduced notably in the neighborhood of the veins. The progressive loss of iron oxides is accounted for by the metasomatic formation of pyrite. Magnesia has been reduced, but lime has not on the whole been greatly af-

${ }^{1}$ J. E. Spurr, loc. cit., sup., p. 216. 
fected. There is a notable loss of soda and gain of potash, except near the vein, where the potash has also been reduced with the intense silicification.

Thus at the two localities selected for examination-Thames and Waihi-the processes were similar, except for the notable silicification at Waihi, and the more intense carbonation at the Thames. In this connection it is worthy of note that great volumes of carbon dioxide were encountered in several of the Thames mines. ${ }^{1}$ The gas evidently represents a residuum which escaped from or was left by the vein-forming solutions, and enclosed in cavities in the veins during their filling.

AGENTS OF THE ROCK-ALTERATION.

The microscopic evidence as already mentioned, shows two types of altered rock, namely, the chloritic type, found almost universally over the whole of the gold fields and not confined to vein-bearing areas, and the completely altered sericitic type, confined to the neighborhood of the veins. The chemical evidence also indicates that the processes of alteration in these two rocks were different. In the first there was a loss of silica and a gain of carbon dioxide, which latter was presumably the agent in the formation of chlorite. The waters in this case, then, were poor in silica and highly carbonated. In the second rock there is a loss of the refractory base, a considerable loss of soda and gain of potash, and introduction of sulphur. The solutions were here rich in potash, sulphur and silica. The differences in the solution, as shown by their effects, do not seem readily explicable by gradual changes in their composition as they circulated laterally from the vein-fissures into the country-rock. Moreover, the widespread alteration of the ferro-magnesian silicates could scarcely have been accomplished by the circulation (of waters) through the great extent and thickness of the solidified rocks, either before or after the period of vein-formation, and this chloritic facies of andesitic rocks is found in many volcanic districts devoid of mineral veins or other evidence of hydro-thermal processes.

${ }^{1}$ Jas. Park, Trans. N. Z. Inst. Min. Eng., I., I897, p. 23. 
The most reasonable explanation seems to be that the chloritization took place immediately after the eruption of the rocks and during their solidification, through the agency of contained solutions or gases rich in carbon dioxide, which is such a characteristic product of volcanic action. In this connection it is noteworthy that the hornblende often shows a resorption border or reaction-rim of chlorite and magnetite, probably due to reactions with gases which saturated the rock during or immediately after the separation of the crystals.

The formation of the sericite-pyrite-carbonate rock, on the other hand, is certainly due to the vein-forming solutions which were at first rich in silica and potash, but became impoverished in these constituents, and gained soda as they seeped into the rocks immediately adjoining the vein-fissures. The corresponding effect on the rock was a concentration of potash and a leaching of soda.

\section{GRAPHIC REPRESENTATION OF CHANGES.}

The chemical changes are illustrated by the following diagrams constructed in accordance with W. H. Hobbs's modification of Broegger's method, ${ }^{1}$ the arms being drawn proportional to the molecular ratios. The first two diagrams, Figs. $a$ and $b$, Plate VIII., constructed from the Thames analyses, show the change from fresh andesite to the chloritic modification. The third and fourth, Figs. $c$ and $d$, Plate VIII., from the Waihi analyses (Nos. I and 6) show the change from fresh dacite to replacement-ore by silicification.

\section{EVIDENCE FROM THERMAL SPRINGS.}

J. E. Spurr has pointed out that thermal springs, having risen through a considerable thickness of rocks, may be expected to have a composition analogous to that of the vein-forming waters after they had penetrated laterally some distance into the rocks. ${ }^{2}$ Analyses of springs in typical New Zealand thermal districts,

\footnotetext{
${ }^{1}$ W. H. Hobbs, "Classification of the Igneous Rocks," Journ. Geol., 8, 1900, p. I.

${ }^{2}$ Loc. cit., sup., pp. $237-238$.
} 


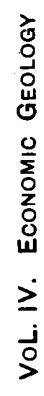
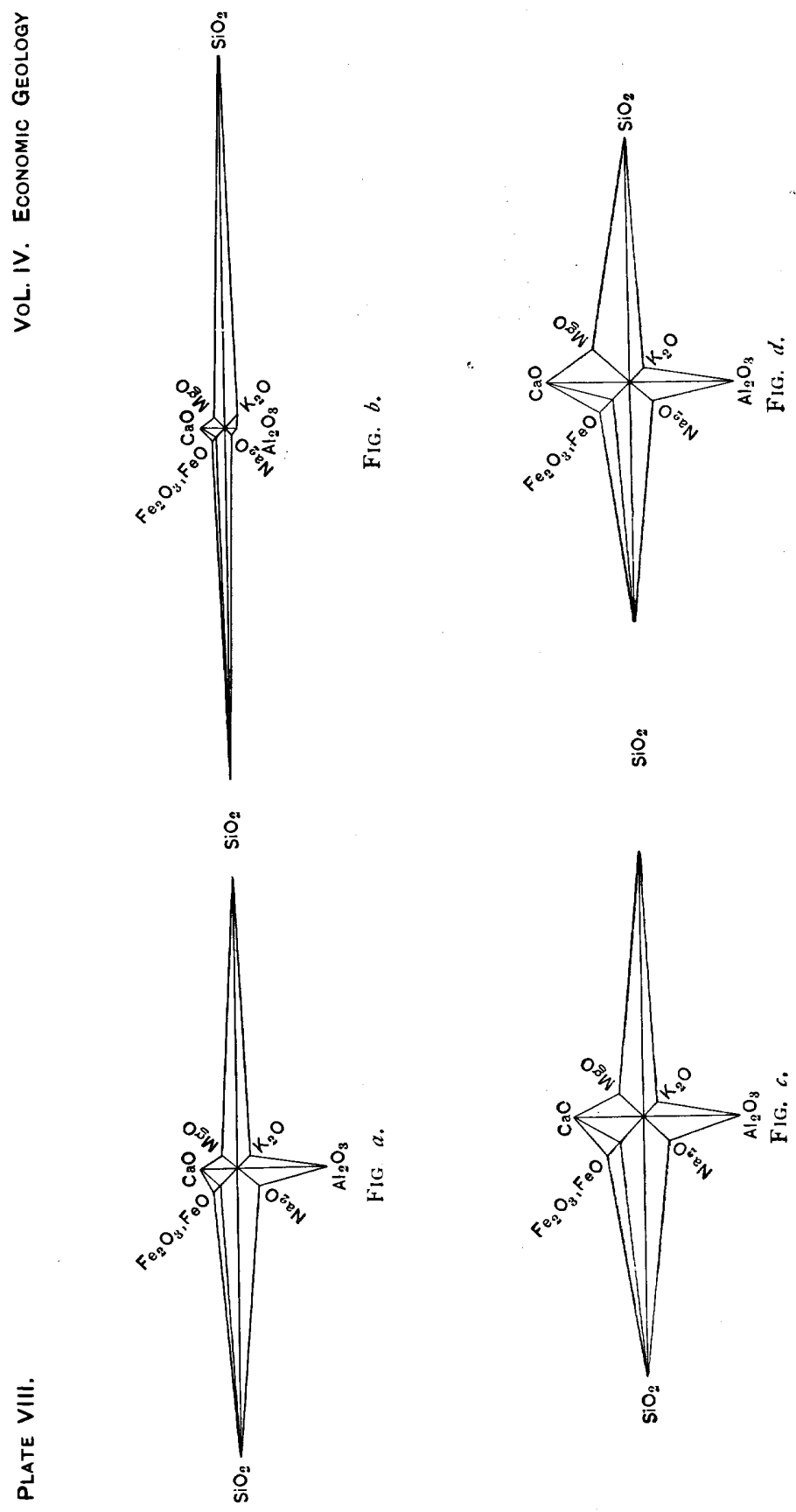

옹

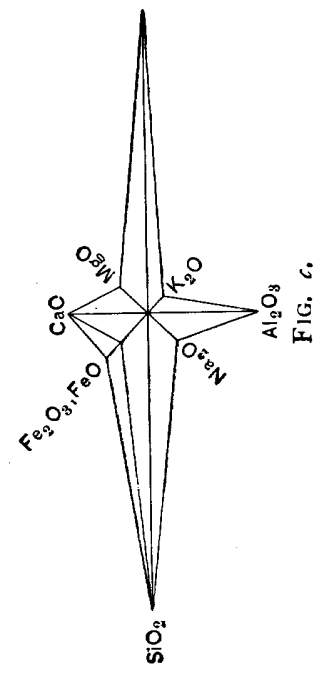


recorded by W. Skey and J. S. Maclaurin, ${ }^{2}$ show generally poverty of silica, and nearly always a great excess of soda over potash. A similar state has been inferred in the case of the veinforming solutions on the Hauraki goldfields, after they had passed into the country-rock from the vein-fissures. The present mineral springs have therefore evidently suffered a continual loss of silica and potash in their ascent and gained soda from the walls of their circulation channels. It is worthy of note that the siliceous sinters of Rotorua contain appreciable quantities of gold and silver. ${ }^{3}$

\section{ORE-SHOOTS AND ORE-DEPOSITION.}

The veins of Hauraki are broadly divisible into two types-a northern and a southern.

\section{NORTHERN TYPE.}

These veins, occurring in the Thames and Coromandel districts, are generally small, and carry bonanzas in irregular shoots of often phenomenal richness. The vein-filling is chiefly massive or comby quartz, the gold is typically coarse and free, with a fineness of from 680 to 700 , and is accompanied by pyrite, arsenopyrite, and other sulphides. The bonanzas are separated by low grade or barren portions of the veins, which are generally poorly mineralized. The bonanza-zone extends to a depth of from 400 to 600 feet below the present surface. At greater depths the veins have seldom been found payable, although there are indications at Coromandel of a lower zone of similar but less rich bonanzas, ${ }^{4}$ as at Cripple Creek. ${ }^{5}$ The ore-shoots are closely dependent on faults, vein-intersections, and leaders. Lindgren concludes that the ore-shoots are of primary origin, ${ }^{6}$ but Morgan inclines to the view that they have resulted from secondary en-

1 Trans. N. Z. Inst., 10, 1877, pp. 423-448.

2 39th Ann. Rep. Col. Lab., Mines Dept., N. Z.

J. M. Bell, ist Ann. Rep. N. Z. Geol. Survey, Ig07, p. 6.

4 Fraser, Bull. No. 4, N. Z. Geol. Survey, I907, p. I00.

${ }^{5}$ Lindgren and Ransome, P. P. No. 54, I906, p. 207.

${ }^{6}$ Lindgren, Eng. and Min. Journal, 79, 1905, p. 219. 
richment by descending waters. ${ }^{1}$ Microscopic examination of the rocks, however, shows that the bonanza zones, although occurring comparatively near the surface, are always enclosed by highly altered andesites, while poorer portions of the veins are frequently associated with comparatively fresh country-rock. This feature is difficult to explain by the action of descending waters, as the rock-alteration is clearly due to ascending thermal solutions. The petrographic evidence, therefore, is in favor of the view that the localization of the ore-shoots is primary, and due to deposition by ascending solutions in a zone rendered "critical" by extensive fissuring with consequent relief of pressure, the ores being continually augmented by the cumulative effects of mass-action. At the same time, it is difficult to account for the extremely rich bonanzas except by processes of secondary enrichment, and it seems highly probable that descending waters have subsequently played a considerable part in the concentration of the ores.

\section{SOUTHERN TYPE.}

These veins are typically developed at Waihi and Karangahake. At $\mathrm{Waihi}^{2}$ the veins are of great width, while the ore-shoots are very uniform and continuous. The free gold is generally invisible and has a fineness of about 645 . Near the surface the veinmaterial is a typical siliceous sinter, oxidized, but not appreciably enriched. At greater depths this is gradually replaced by primary sulphide-ore, composed of finely crystalline quartz, with a little calcite and valencianite, and impregnated with finely divided pyrite, argentite and blende. The gold values occur mainly in the pyrite, and the ratio of gold to silver in the ore is $\mathrm{I}: 6$. This sulphide-ore is typically a product of replacement of the countryrock, as has been seen in the analyses discussed above, and this is also evident from the manner in which the veins shade off by degrees into barren rock, without any defined walls. Under the microscope the vein-material appears as a fine mosaic of granular quartz, with occasional pseudomorphs of adularia, and patches

${ }^{1}$ Morgan, N. Z. Mines Record, 8, 1905, p. 465.

${ }^{2}$ Bell and Fraser, Canadian Min. Journ., 29, 1908, pp. 388 and 420. 
of carbonates and sericite, the whole impregnated with grains and strings of sulphides.

In the deeper levels this replacement-ore is frequently traversed by numerous parallel strings and veinlets of quartz, argentite and pyrite, giving a finely banded appearance to the ore. This banded sulphide-ore, carrying gold to silver in the ratio of $I: 30$, constitutes some of the richest ore mined at Waihi. The suggestion that it may be due to a later period of mineralization than the original replacement-ore, ${ }^{1}$ is confirmed by microscopic examination. This shows it to consist of close-set parallel strings of quartz, often banded and comby, alternating with seams and strings of pyrite and argentite. Examinations of the adjoining rock shows that it also is traversed by numerous veinlets of quartz and sulphides, of later date than the alteration of the rocks.

There have thus been at Waihi and in similar districts, either two successive periods of mineralization, or else a prolonged period of mineralization, during whcih the character of the ore deposited underwent a change. The earliest phase was characterized by extensive silicification and replacement of the adjoining rocks, and to this the great width of some of the veins is chiefly due. The later phases were marked by the deposition of more highly argentiferous ore along portions of the veins which had been partially reopened or fractured by movement, and had thus given access to the solutions. The alteration of the rocks was effected during the earlier stages, the products then formed being stable and unaffected by the circulation of subsequent solutions. The later mineralization accounts for the uniform and often improved value of the ore in depth, and as the highest level of deposition was then apparently at a considerable depth beneath the outcrop, the deep zone which has been thus enriched may reasonably be expected to persist for some depth to come.

\section{SOURCE OF THE PRECIOUS METALS.}

Bela von Inkey has recently, while emphasizing the universal association of grünstein (propylitic facies) with the tertiary an-

${ }^{1} I d .$, ib., p. 420. 
desitic gold fields, called attention to the desirability of further chemical examination of the fresh rocks for gold and silver, and suggested that the metals were originally contained chiefly in the hornblende, from which they were leached out by the solutions which at the same time effected the chloritization. ${ }^{1}$ But the same widespread alteration of andesites is found in regions where there are no gold-veins. The view that the ores of Hauraki were derived from the surrounding andesites was advocated by F. W. Hutton, ${ }^{2}$ but Dr. J. R. Don, after a series of exhaustive tests, failed to find gold in the unaltered rocks. ${ }^{3}$ Further, assays now in progress in the laboratory of the New Zealand Geological Survey are stated to be in confirmation of Don's results. ${ }^{4}$ It may possibly be found that the unaltered ferro-magnesian silicates of these rocks do contain traces of gold and silver, a matter which the writer has not had the opportunity to investigate. Even, however, with that fact established, the theory that these silicates were the direct source of the ores in the veins encounters great difficulties, since it seems most probable that the solutions which effected the chloritization of the ferro-magnesian minerals were active during the consolidation of the successive flows, and gradually escaped upwards under low pressure, whereas the solutions which mineralized the veins rose from considerable depths at a distinctly later period.

It seems most reasonable, in the case of gold-fields of this type, to conclude that the rocks arose from a magma, in which or in portions of which the metals were segregated, and from which they were subsequently transported in solutions freed by the formation of fissures in the overlying solidified lavas and tuffs.

The writer is indebted to Mr. Colin Fraser of the New Zealand Geological Survey, for a series of rock-specimens from the Thames, and to Professor W. W. Watts of the Imperial Col-

${ }^{1} \mathrm{~B}$. von Inkey, “La relation entre l'état propylitique des roches andésitiques et leurs filons mineraux," Internat. Geolog. Congress, sess. Io, 1906, Vol. I., p. 50 I et seq.

${ }^{2}$ Rep. Austr. Assoc. Adv. Sci., I., 1887, pp. 245-274.

${ }^{8} \mathrm{~J}$. R. Don, "Genesis of Certain Auriferous Lodes," Trans. A. I. M. E., 27,1897, p. 564 et seq.

${ }^{4}$ Bull. No. 4, N. Z. Geol. Survey, I907, p. 107. 
lege of Science, London, for granting facilities in the laboratory and for suggestions and criticisms.

\section{BIBLIOGRAPHY.}

The literature on these gold fields is fairly extensive, but scattered. The following list includes the more important papers.

J. M. Bell and C. Fraser. The Great Waihi Gold Mine. Canadian Mining Journal, Vol. 29, I908, pp. 388 and 420.

Lairua Gold Field. Austr. Mining Standard, 39, I908, p. 608.

S. H. Cox. Gold Fields of Cape Colville Peninsula. Rep. N. Z. Geol. Survey, 1882 , p. 4 .

C. Fraser and J. H. Adams. Geology of Coromandel, Hauraki. Bull. No. 4, N. Z. Geol. Survey, I907.

F. W. Hutton. Rocks of the Hauraki Gold Fields. Rep. Austr. Assoc. Adv. Sci., I., I887, p. 245.

w. Iindgren. The Hauraki Gold Fields, New Zealand. Eng. and Min. Journal, Vol. 79 (I905), p. 218.

J. M. Maclaren. Geology of Coromandel Gold Field. Ann. Rep. Mines Dept. N. Z., C-9, 1900 .

Alex. McKay. Geology of Cape Colville Peninsula. Ann. Rep. Mines Dept. N. Z., C-3, I897.

P. G. Morgan. Geology, Quartz Reefs and Minerals of Waihi. Trans. Aust. Inst. Min. Eng., 8, I902, p. I66.

Hauraki Gold Fields. N. Z. Mines Record, Vol. 8, 1905, p. 370.

James Park. Geology of the Thames Gold Field. Ann. Rep. Mines Dept. C-3, I894.

Geology of Hauraki Gold Fields. Trans. N. Z. Inst. Min. Eng., I., I897, p. 3 .

W. J. Sollas and Alex. McKay. Rocks of Cape Colville Peninsula. 2 vols., Wellington, I905-I906. 